\title{
Effect of wintering area and climate on the survival of adult Atlantic puffins Fratercula arctica in the eastern Atlantic
}

\author{
Michael P. Harris ${ }^{1, *}$, Tycho Anker-Nilssen ${ }^{2}$, Robin H. McCleery ${ }^{3}$, \\ Kjell Einar Erikstad ${ }^{4}$, Deryk N. Shaw ${ }^{5}$, Vladimir Grosbois ${ }^{6,7,8}$ \\ ${ }^{1}$ NERC Centre for Ecology and Hydrology, Hill of Brathens, Banchory, Aberdeenshire AB31 4BW, UK \\ ${ }^{2}$ Norwegian Institute for Nature Research (NINA), 7485 Trondheim, Norway \\ ${ }^{3}$ Edward Grey Institute, Department of Zoology, University of Oxford, South Parks Road, Oxford OX1 3PS, UK \\ ${ }^{4}$ Norwegian Institute for Nature Research (NINA), The Polar Environmental Centre, 9296 Tromsø, Norway \\ ${ }^{5}$ Fair Isle Bird Observatory Trust, Fair Isle, Shetland ZE2 9JU, UK \\ ${ }^{6}$ University of Antwerp, Campus Drie Eiken, Department of Biology, 2610 Antwerp, Belgium \\ ${ }^{7}$ Lighthouse Field Station, University of Aberdeen, Cromarty, Ross-shire IV11 8YJ, UK
}

${ }^{8}$ Present address: Centre d'Ecologie Fonctionnelle et Evolutive, Unité Mixte de Recherche 5175, 1919 route de Mende, 34293 Montpellier cedex 5, France

\begin{abstract}
Despite contrasting population trends ranging from -3 to $+11 \%$ per annum, the annual survival rates of Atlantic puffins Fratercula arctica in the 5 colonies spanning the species range in the east Atlantic were virtually identical over a 10 to $15 \mathrm{yr}$ period, giving no support to the hypothesis that variation in population growth rates is driven by adult survival. The extent to which survival varied among years differed markedly between colonies. Similarities between colonies in the patterns of inter-annual variation in survival did not reflect similarities in wintering areas, as indicated by recoveries of ringed birds, nor the geographic proximity of the colonies. However, survival in 4 of the 5 colonies correlated with sea surface temperatures around each colony 2 yr earlier. The relationship between survival and sea temperature was positively correlated with the effects of sea temperature on recruitment of the Atlantic puffin's main prey species, the lesser sandeel Ammodytes marinus, the herring Clupea harengus and the capelin Mallotus villosus.
\end{abstract}

KEY WORDS: Adult survival $\cdot$ North Atlantic Oscillation $\cdot$ Sea surface temperature $\cdot$ Population regulation

Resale or republication not permitted without written consent of the publisher

\section{INTRODUCTION}

In long-lived birds that have delayed sexual maturity and a small clutch size, the annual survival of breeding adults is often seen as the main factor influencing the rate of population change (Croxall \& Rothery 1991, but see Nur \& Sydeman 2000). The Atlantic puffin Fratercula arctica is such a species, having an annual survival rate of adults of 90 to $95 \%$, an age at first breeding of $5 \mathrm{yr}$, and an invariant single-egg clutch (Harris 1984). It is a highly abundant piscivorous species, endemic to the colder parts of the North Atlantic Ocean, breeding from the Bay of Fundy in the west,
Brittany in the east, and north to the high arctic. Populations in various parts of the range have shown very different population trajectories over the past few decades. Thus numbers in colonies in the North Sea and the far NE of Norway have increased at rates of up to $11 \% \mathrm{yr}^{-1}$ at the same time that populations in central Norway have declined at $3 \% \mathrm{yr}^{-1}$ (Barrett 2001, AnkerNilssen \& Aarvak 2004, Harris \& Wanless 2004). The survival of adult Atlantic puffins has been monitored for several colonies spanning almost the entire latitudinal range in the E Atlantic, and the results allowed us to investigate the hypothesis that changes in numbers are governed by differences in adult survival. 
Little detailed information is available for the Atlantic puffin when it is away from the breeding colonies in the E Atlantic, but the species occurs mainly well offshore, with birds dispersed at very low density over vast areas of ocean from the Barents Sea south to the Azores and the Canary Islands, west to Greenland and Newfoundland and east to Italy in the Mediterranean (Harris 1984, 2002, Stone et al. 1995, Bakken et al. 2003). Ringing of Atlantic puffins in colonies throughout the range suggested that adults from different populations have differing wintering areas (Myrberget 1973, Anker-Nilssen \& Tatarinkova 2000, Harris 2002) and so might be influenced in different ways by climate change. We investigated factors influencing adult survival in these colonies using 2 approaches. First, we determined the pattern of correlation between time series of adult survival rates in 5 colonies and examined whether this pattern was compatible with the degree of overlapping of the wintering areas of the birds as assessed from ring recoveries and/or with the pattern of correlation between time series of local environmental variables in the vicinity of the 5 colonies. Second, we addressed directly the correlation between adult survival rates and large- and local-scale environmental variables.

\section{MATERIALS AND METHODS}

Study colonies. The survival of Atlantic puffins was studied for 5 colonies: Skomer (Wales), Isle of May and Fair Isle (Scotland), and Røst and Hornøya (Norway), covering almost $20^{\circ}$ of latitude (see Fig. 1). Details of the colonies are given in Table 1 . At the beginning of the study the breeding population size of these colonies varied from 7000 pairs (at Skomer) to 660000 pairs (at Røst) and the current population status also showed contrasting trends from rapid increase (Isle of May, Fair Isle and Hornøya), through stability (Skomer) to consistent decline (Røst) (Barrett 1983, Anker-Nilssen \& Røstad 1993, Anker-Nilssen \& Øyan 1995, Harris et al. 2003, Harris \& Wanless 2004). In all colonies the diet of chicks (and apparently adults) comprises small fishes, notably the lesser sandeel Ammodytes marinus on Skomer, Isle of May and Fair Isle, young herring Clupea harengus on Røst, and sandeels and capelin Mallotus villosus on Hornøya (Harris 1984, Anker-Nilssen 1992, Barrett 2002, Durant et al. 2003, Anker-Nilssen \& Aarvak 2004). Breeding success also varied greatly between colonies, being high at most colonies, but lower and more variable on Røst (Harris 1984, Anker-Nilssen \& Øyan 1995, Barrett 2002, Durant et al. 2003, Anker-Nilssen \& Aarvak 2004)

Bird capture histories. In each colony, breeding adults were caught and marked with a numbered metal ring, and either an individually coded colourring (Røst from 1998 onwards) or a unique combination of colour rings (other colonies and Røst 1990 to 1997). In each subsequent year, visual searches were made for these birds predominantly in the areas where they had been ringed, but also in other parts of the colony. Throughout the period, additional birds were marked to replace those disappearing. The years for which survival was assessed and the numbers of adults involved are shown in Table 1. The actual data in the form of $\mathrm{m}$-arrays are presented in Appendix 1. On the Isle of May and Røst, most birds were sexed by bill or head + bill measurements (Harris 1984, Anker-Nilssen \& Brøseth 1998). The sex of ringed individuals from the other colonies was unknown.

Winter dispersal data. Outside the breeding season, Atlantic puffins are pelagic and are rarely seen close to

Table 1. Fratercula arctica. Characteristics of the studied colonies. References are given in the text. SST: sea surface temperature; Period covered: period covered by capture-resighting data set; Sample size: size of same data set; Breeding success: this was lagged $5 \mathrm{yr}$ (growth from fledgling to breeding adult); Breeding pairs: number at start of monitoring period

\begin{tabular}{|c|c|c|c|c|c|c|c|c|}
\hline Colony & Coordinates & $\begin{array}{c}\text { Area for } \\
\text { local SST } \\
\text { data }\end{array}$ & $\begin{array}{l}\text { Main prey } \\
\text { in breeding } \\
\text { season }\end{array}$ & $\begin{array}{l}\text { Period } \\
\text { covered }\end{array}$ & $\begin{array}{c}\text { Sample } \\
\text { size }\end{array}$ & $\begin{array}{l}\text { Breeding } \\
\text { success means } \\
\text { (range) }\end{array}$ & $\begin{array}{l}\text { Breeding } \\
\text { pairs }\end{array}$ & $\begin{array}{c}\text { Population } \\
\text { trend } \\
\left(\% \mathrm{yr}^{-1}\right)\end{array}$ \\
\hline Skomer & $\begin{array}{r}51^{\circ} 45^{\prime} \mathrm{N} \\
5^{\circ} 18^{\prime} \mathrm{W}\end{array}$ & $\begin{array}{c}51^{\circ}-53^{\circ} \mathrm{N} \\
4^{\circ}-7^{\circ} \mathrm{W}\end{array}$ & Sandeel & 1984-2002 & 647 & $\begin{array}{c}0.76 \\
(0.67-0.87)^{\mathrm{a}}\end{array}$ & $6700^{\mathrm{d}}$ & 0 \\
\hline Isle of May & $\begin{array}{r}56^{\circ} 11^{\prime} \mathrm{N} \\
2^{\circ} 34^{\prime} \mathrm{W}\end{array}$ & $\begin{array}{c}55^{\circ}-57^{\circ} \mathrm{N} \\
0^{\circ}-3^{\circ} \mathrm{W}\end{array}$ & Sandeel & $1984-2002$ & 408 & $\begin{array}{c}0.82 \\
(0.69-0.93)^{\mathrm{a}}\end{array}$ & 12000 & +11.8 \\
\hline Fair Isle & $\begin{array}{r}59^{\circ} 32^{\prime} \mathrm{N} \\
1^{\circ} 38^{\prime} \mathrm{W}\end{array}$ & $\begin{array}{c}59^{\circ}-61^{\circ} \mathrm{N} \\
0^{\circ}-3^{\circ} \mathrm{W}\end{array}$ & Sandeel & 1986-2002 & 277 & $\begin{array}{c}0.72 \\
(0.57-0.87)^{\mathrm{a}}\end{array}$ & 20000 & +5.1 \\
\hline Røst & $\begin{array}{l}67^{\circ} 26^{\prime} \mathrm{N} \\
11^{\circ} 52^{\prime} \mathrm{E}\end{array}$ & $\begin{array}{l}66^{\circ}-68^{\circ} \mathrm{N} \\
10^{\circ}-14^{\circ} \mathrm{E}\end{array}$ & Herring & 1990-2002 & 373 & $\begin{array}{c}0.42 \\
(0.00-0.96)^{b}\end{array}$ & 660000 & -3.2 \\
\hline Hornøya & $\begin{array}{c}70^{\circ} 27^{\prime} \mathrm{N} \\
31^{\circ} 9^{\prime} \mathrm{E}\end{array}$ & $\begin{array}{l}70^{\circ}-72^{\circ} \mathrm{N} \\
29^{\circ}-34^{\circ} \mathrm{E}\end{array}$ & $\begin{array}{l}\text { Sandeel and } \\
\text { capelin }\end{array}$ & 1990-2002 & 689 & $\begin{array}{c}0.85 \\
(0.78-0.92)^{\mathrm{c}}\end{array}$ & 8400 & +2.0 \\
\hline
\end{tabular}


land (Stone et al. 1995). Recoveries of ringed Atlantic puffins reported between 1 August and 31 March were obtained from the British and Norwegian Ringing Schemes. We only used recoveries of birds ringed as full-grown birds or as chicks that had survived at least $3 \mathrm{yr}$ after ringing, by which time they are regularly attending colonies. The few recoveries of long-dead birds in or near the colonies in August were omitted. Recoveries of local birds close to the Isle of May in March were excluded since adults at this colony return from late February onwards. To increase sample sizes available for analysis, we added recoveries of Atlantic puffins ringed at other colonies near to Skomer (within $100 \mathrm{~km})$, Isle of May (100 km), Fair Isle (Shetland colonies within $150 \mathrm{~km})$, Røst $(120 \mathrm{~km})$ and Hornøya (colonies in Norway along $650 \mathrm{~km}$ of coast north of $69^{\circ} \mathrm{N}$ ) to those from the colonies themselves.

Environmental factors underlying temporal variation in survival probability. The limited data available suggest that most adult Atlantic puffins die during the nonbreeding season. For instance, between 1990 and 1994, only 1 of 30 birds (3\%) that disappeared from intensively studied burrows on the Isle of May between one spring and the next did so during the breeding season; the remainder were present at the end of July but did not return the next April (C. V. Wernham pers. comm.). Less intensive observations over the rest of the period provided additional support for this. We therefore looked for environmental factors that might have influenced survival outside the breeding season. The North Atlantic Oscillation (NAO) is an atmospheric phenomenon that influences winter climatic conditions over the whole North Atlantic region (Hurrell et al. 2003). We considered NAO in winter from December to March (hereafter referred to as wNAO) as a potential proxy for the climatic conditions during the winter. Furthermore, since wNAO reflects variations in the dynamics and composition of several North Atlantic phytoplankton, zooplankton and fish communities (Planque \& Taylor 1998, Ottersen et al. 2001, Arnott \& Ruxton 2002, Attril \& Power 2002, Edwards et al. 2002, Hjermann et al. 2004), we used it as a proxy for food abundance for the Atlantic puffin during the winter and/or the breeding season. Since effects of the wNAO on lower trophic levels might take time to reach higher levels, wNAOs lagged by 1 and 2 yr were also considered. Values for the wNAO were downloaded from www.cgd.ucar.edu/cas/jhurrell/indices.html.

The influence of sea surface temperatures (SST) on the abundance of forage fishes that are important for Atlantic puffins is well documented. In particular, Arnott \& Ruxton (2002) found a negative correlation between summer recruitment of 0 -group (first-year) sandeels in the North Sea and SST during the sandeel larval period (January to May). Conversely, a positive relationship between sea temperature during winter and recruitment of 0 -group (first-year) herring has been documented for the Norwegian and Barents Seas (Toresen \& Østvedt 2000, Sætre et al. 2002). SST in the vicinity of the Atlantic puffin colonies during January to May of Year Y and of Year Y-1 are thus likely to be associated with 0-group and 1-group (second-year) abundance of key prey species for the Atlantic puffin during and after the breeding season of Year Y.

We also considered that local environmental conditions (reflected by SST) prevailing in the vicinity of the colony during the breeding season (May to July) could affect subsequent survival of adult Atlantic puffins. Monthly SST blended from ship, buoy and bias-corrected satellite data at a resolution of $1^{\circ}$ longitude by $1^{\circ}$ latitude (Reynolds et al. 2002) were obtained from http://iridl.ldeo.columbia.edu/SOURCES/.IGOSS/.nm c/.Reyn_SmithOIv2/.monthly/.sst/. For each colony, 6 to 10 cells of the grid were selected such as to represent an area of sea of about $40000 \mathrm{~km}^{2}$ around the colony under study, and averages were computed for these cells over 2 periods: the spawning season and larval period of the main prey species (January to May) and the breeding season of the Atlantic puffin (May to July). The pattern of spatial correlation between local SST time series was investigated using 'proc corr' of SAS Version 8.02 statistical package (SAS 1999).

Capture history analysis. Capture histories of adult Atlantic puffins were analysed using specific procedures developed to provide robust estimates of survival probabilities (hereafter referred to as $\Phi$ ), while accounting for potential biases due to variation in resighting probabilities (hereafter referred to as $p$ ). A logit-link function was used to constrain the estimates of $\Phi$ and $p$ between 0 and 1 . The statistical package MARK 5.0 (White \& Burnham 1999) was used to obtain maximum likelihood estimates of survival and resighting probabilities, and fit statistics, under various models.

Goodness-of-fit: Before using capture-resighting models for hypothesis-testing, a departure model has to be defined that adequately fits the data (Lebreton et al. 1992). To check for the goodness-of-fit (GOF) of departure models and identify the causes of any lack of fit (i.e. heterogeneities in survival and/or recapture probabilities), tests were conducted with software UCARE 2.0 (Choquet et al. 2001) that assesses the GOF of the Cormack-Jolly-Seber model, in which survival and resighting probabilities are fully time dependent (i.e. model $\Phi$ (year), $p$ (year)). The GOF of model $\Phi$ (year) $p$ (year) was assessed independently for the data sets of each colony and each sex for the 2 colonies for which this information was available. For all 7 data sets considered, model $\Phi$ (year), $p$ (year) fitted the data very poorly (all $p<0.01$ for the sum of the components of the GOF test). Examination of the different components of 
the test revealed that the lack of fit was due to a traphappiness effect (all $\mathrm{p}<0.0001)$. Individuals were more likely to be resighted if they had been resighted on the previous occasion. This effect probably reflected heterogeneity in recapture probability within and/or between capture-resighting histories rather than a genuine influence of the resighting process on the probability of resighting in the following year. Heterogeneity between capture histories would not be surprising since the probability of resighting seabirds on breeding grounds is likely to be related to components of the breeding performance such as intermittent breeding, probability of failing at an early stage of reproduction or nest attendance and since numerous seabird studies have demonstrated inter-individual heterogeneity in these components of breeding performance (e.g. Cam et al. 1998). Heterogeneity within individual capture histories could reflect a positive temporal autocorrelation within individuals in the components of breeding performance listed above and could be explained, for example, by age-related variation in these components (e.g. Wooller et al. 1990). The investigation of the mechanisms generating heterogeneity in resighting probability is beyond the scope of the present paper, nonetheless, heterogeneity in recapture probability was accounted for by introducing a factor 'years since last resighting' in the model, describing the variation in resighting probability (Pradel 1993). We considered 4 such 'years since last resighting' classes $(1,2,3$, and more than 3 yr after last resighting, referred to as ' $a_{4}{ }^{\prime}$ ) in the departure model for each colony. The other components of the GOF test (3SR and 3SM) address heterogeneities in survival probabilities. They did not show any significant departure from the null hypothesis (all $\mathrm{p}>0.15$ ) except for the Skomer data set $(p=0.04)$. This slight lack of fit was allowed for by scaling down the deviance of the models built for this data set by an over-dispersion parameter equal to the ratio of the $\chi^{2}$ statistic associated with test $3 \mathrm{SR}+3 \mathrm{SM}$ to the number of degrees of freedom associated with this statistic: $52.3 / 36=1.45$.

Reference models: Initially the effects of year on survival and resighting probabilities, and of years since last resighting on resighting probabilities were assessed independently for each colony. This defined a reference model for each colony that captured the most important general sources of variation in survival and resighting probability, without relying on specific assumptions concerning the covariates underlying their temporal variation. The most complex model, i.e. the one with most parameters, considered was $\Phi$ (year) $p\left(a_{4}+\right.$ year $)$ except for the Isle of May and Røst, where it was $\Phi($ year + sex + year $\times \operatorname{sex}) p\left(a_{4}+\right.$ year + sex $+a_{4}$ $\times$ sex + year $\times$ sex $)$. Starting from this model, a stepdown selection procedure was performed in order to define a reduced model that adequately fitted the data. The set of reduced models comprised those in which only 3 and 2 'yr since last resighting' classes were considered for resighting probability. The model selection criterion used combined the parsimony principle and a form of Akaike's information criterion modified for data sparseness (AICc) and, for the Skomer data, for over-dispersion (QAICc) (Lebreton et al. 1992, Burnham \& Anderson 1998). Models with AICc differing by less than 2 points were considered to describe the data equally well and the model with the fewest parameters was preferred.

Descriptive statistics for adult survival rates: Mean survival rates over the study period were derived from a model in which survival was constrained to be constant over years. To avoid an unrealistic estimate $(=1)$ caused by convergence problems in the likelihood optimisation procedure, the estimate for Fair Isle was obtained from a model where survival probability was constrained to be constant in 1990 to 1996 and 1997 to 2001 but allowed to be different in 1996 to 1997. Estimates for different colonies were compared within all possible pairs of colonies using $Z$-tests for differences between logit-transformed mean survival estimates (Lebreton et al. 1992). In order to obtain an estimate of the temporal process variance in survival probability for each colony (referred to as $\hat{\sigma}^{2}$ ) that was corrected for the sampling variance (Gould \& Nichols 1988), a variance component procedure was performed based on a model in which the pattern of variation in survival was estimated without any constraint (i.e. model $\Phi[$ year]). We used the variance decomposition method implemented in MARK (White \& Burnham 1999).

Similarities in pattern of temporal variation in adult survival rates: The similarity within pairs of colonies in the pattern of inter-annual variation in adult survival rate was expressed using the fraction of the total temporal deviance accounted for by a common pattern of variation. We included the capture histories of the individuals from 2 colonies and computed models in which (1) the patterns of variation in survival was allowed to differ in the 2 colonies ( $\Phi$ [year + colony + colony $\times$ year]); (2) survival was forced to exhibit parallel variations in the two colonies ( $\Phi[$ year + colony]), and (3) survival was forced to be constant over time in the 2 colonies. ( $\Phi[$ colony]). The fraction of deviance accounted for by the common pattern of variation was computed as the ratio of (deviance [model $\Phi($ colony)] - deviance [model $\Phi($ year + colony)] ) to (deviance [model $\Phi($ colony)] deviance [model $\Phi($ year + colony + colony $\times$ year $)]$ ). This statistic is an equivalent for maximum likelihood models of the coefficient of determination $\left(\mathrm{R}^{2}\right)$ in analysis of variance models, and is hereafter referred to as ' $\mathrm{R}^{2}$ '. 
Detecting environmental factors underlying interannual variation in adult survival rates: We tested the effect of the covariates potentially underlying interannual variation in adult survival rates independently for each colony, after centring covariates reflecting temporal variation in environmental conditions around the average and standardising them by the standard deviation in the time series covering the study period (White \& Burnham 1999). Starting where survival was constrained to be time-invariant, we performed a step-up selection of the covariates that showed the strongest correlation with adult survival rates. $\mathrm{R}^{2}$ was used as a selection criterion. At each step of the procedure and for each candidate covariate, we computed models in which (1) the pattern of variation in survival was estimated without any constraint ( $\Phi[$ year]); (2) survival variation was forced by logit linear relationship(s) with the focal climatic and/or oceanic factor(s) ( $\Phi[$ year + covariate(s)]), and (3) survival was forced to be constant over time $(\Phi[\mathrm{cst}])$. The $\mathrm{R}^{2}$ of the covariate model was then computed as the ratio of \{deviance $\Phi[\mathrm{cst}]-$ deviance [model $\Phi$ (covariate[s])]) to (deviance [model $\Phi(\mathrm{cst})]$ - deviance [model $\Phi($ year)]\}. A covariate was selected if its incorporation increased the $\mathrm{R}^{2}$ associated with the covariate model by at least $20 \%$. We based covariate selection on biological significance (reflected by $R^{2}$ ) rather than on statistical significance (reflected by the p-value) because statistical significance depends on the statistical power, which obviously varies between data sets of different sizes and thus between colonies. However, we derived ANODEV p-values (Skalski et al. 1993) as measurements of the degree of confidence in the existence of the relationships between adult survival rate and the covariates.

\section{RESULTS}

\section{Winter dispersal}

There were marked differences in the patterns of recoveries from birds ringed in different areas (Fig. 1). Birds from the Isle of May area (340 recoveries) were mainly found in the North Sea. The majority came from the east coast of Britain, with relatively few in the SE North Sea, where Atlantic puffins are generally rare (Stone et al. 1995), but with some $(<10 \%)$ in the Faeroe Islands, the western seaboard of Britain and Ireland and the Bay of Biscay. In contrast, the main wintering areas of Atlantic puffins from the Fair Isle (16 recoveries) and Skomer (59) areas were to the south of Britain, presumably mainly in the Atlantic Ocean, with some entering the Mediterranean and the Norwegian Sea. However, the few recoveries of birds ringed in the Fair Isle area (see next paragraph) mean that it is by no means certain that the bulk of the birds from these 2 areas wintered in the same area. The recoveries from the Røst area (18) and colonies further north (8) suggest that birds from these areas winter in the southern Norwegian Sea and the northern North Sea. Too few

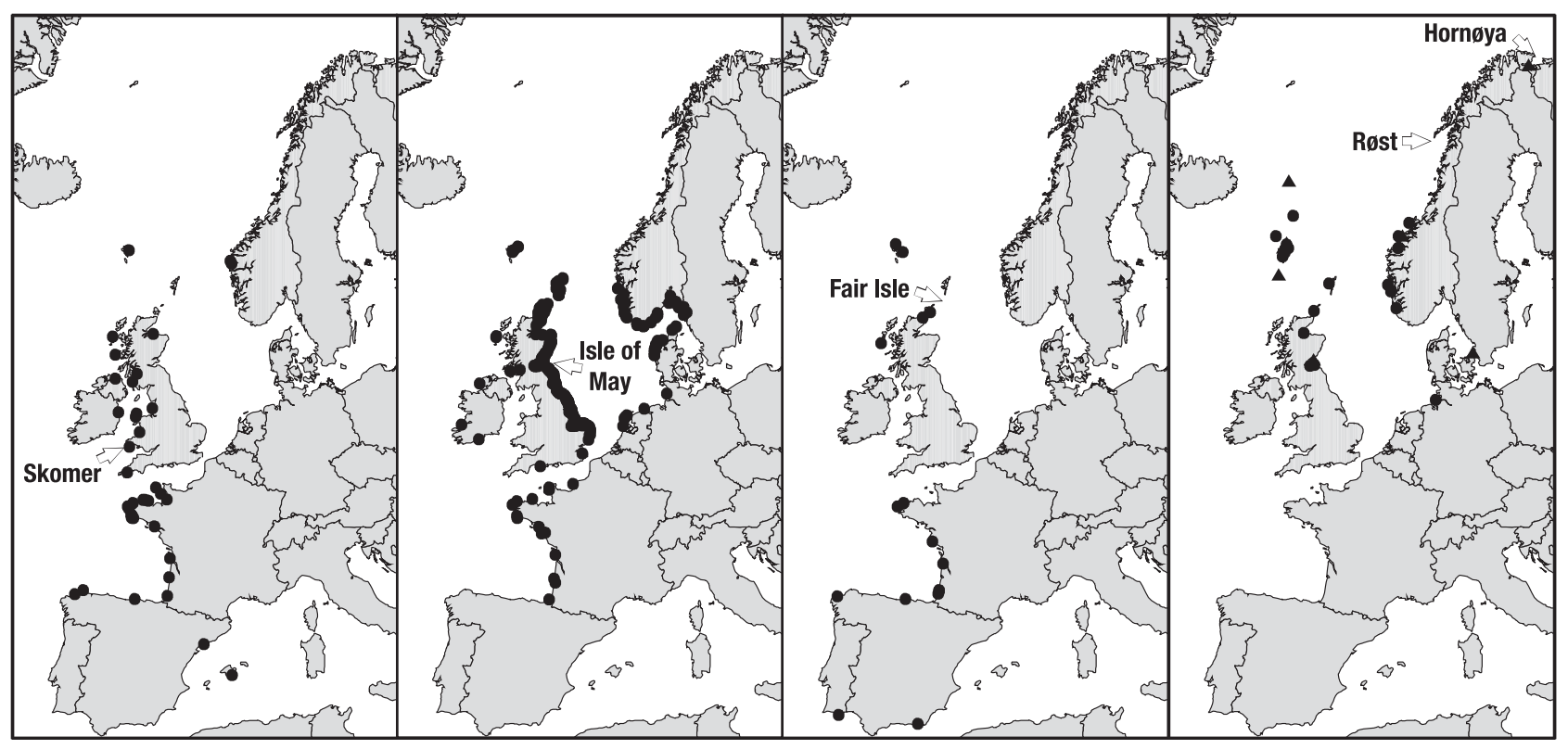

Fig. 1. Fratercula arctica. Geographical location of 5 colonies studied and locations of recoveries of Atlantic puffins ringed at or near Skomer $(\mathrm{n}=59)$, the Isle of May $(\mathrm{n}=340)$, Fair Isle $(\mathrm{n}=16)$, Røst $(\mathrm{n}=18)$ and Hornøya $(\mathrm{n}=8)$ reported dead outside breeding season when at least $3 \mathrm{yr}$ old. (₫) Individual recoveries of birds from Hornøya; $(\bullet)$ recoveries of birds from the other 4 locations 

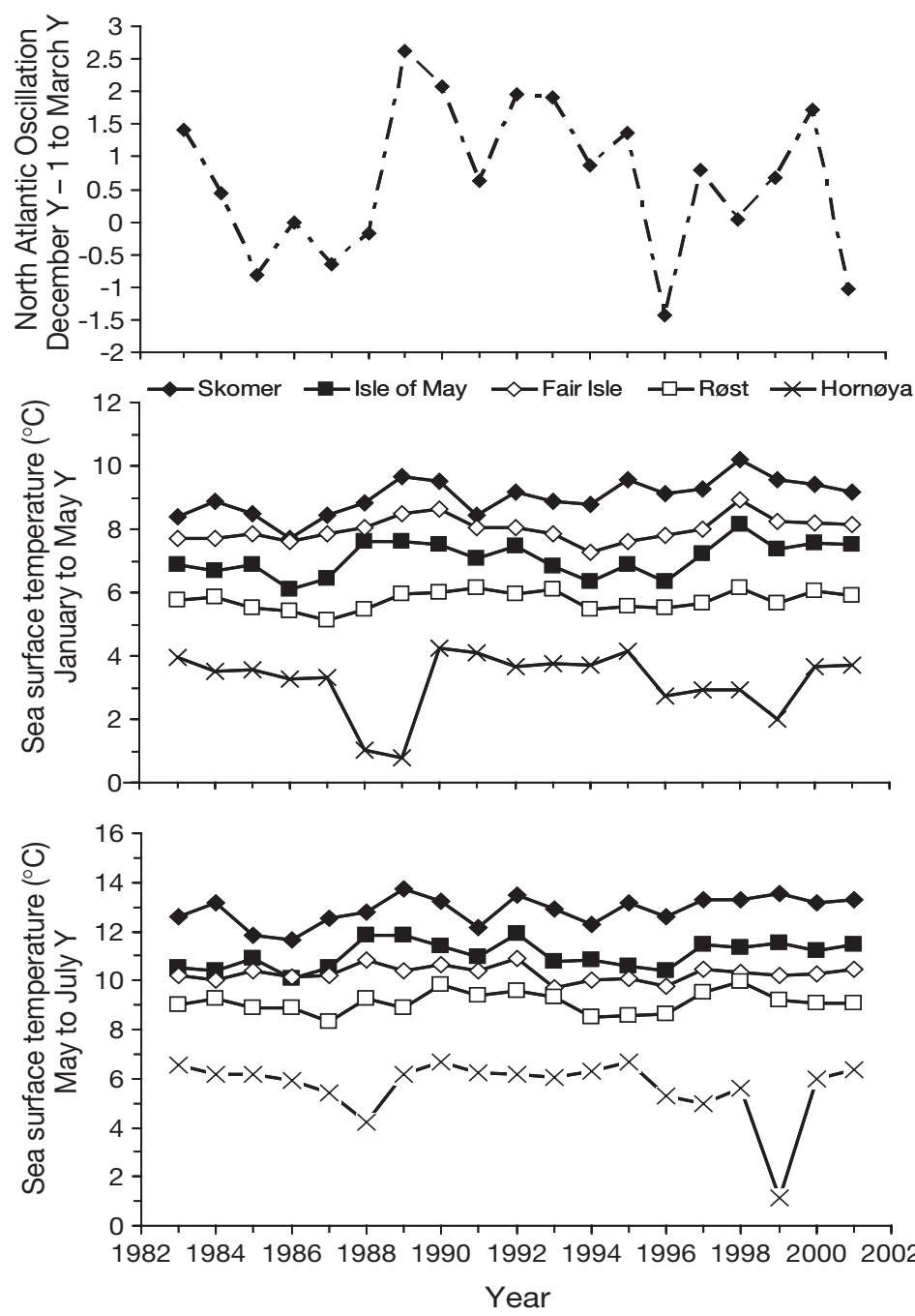

Fig. 2. Annual measures of winter North Atlantic Oscillation (wNAO) and Sea Surface Temperature (SST) in the seas around the 5 colonies in Year Y (with December of the previous year included in the wNAO) (see text) resulted in just $9(0.05 \%), 8(0.06 \%)$ and $2(0.09 \%)$ winter recoveries, respectively. In contrast 32888 and 4859 Atlantic puffins ringed on the Isle of May and Skokholm (10 km from Skomer) resulted in 170 (0.5\%) and $29(0.6 \%)$ recoveries, respectively, recovery rates 5 to 10 times higher than for the 3 other colonies. Considering coastline topography and sea currents, this marked difference in recovery rates is probably due to the relatively higher chance of a bird dying in the North Sea and the Bay of Biscay being found and reported, compared to the presumably far lower chances of finding birds wintering along the Norwegian coast or far offshore. The chances of recovery are further reduced to the north, where shores are rocky and areas more sparsely populated than in mainland Europe. The paucity of recoveries in the North Sea from the colonies other than the Isle of May does, however, suggest that few birds from these 4 colonies winter in this area. The concentration of recoveries around the Faeroe Islands of birds from all colonies was undoubtedly due to the high numbers of auks shot there during the winter, but does indicate an overlap in wintering areas in those waters.

\section{Pattern of spatial correlation between local SST time series}

The correlations between local SST at different locations are shown in Table 2, with time series plotted in Fig. 2. The pattern of correlation did not differ whether we considered the period covered by the longest survival time series (1984 to 2000) or only the period covered by all the survival time series (1990 to 2001). Furthermore, January to May SSTs and May to July SSTs showed similar spatial correlation patterns, although correlations for the former were generally higher. recoveries were available to determine differences in the wintering areas of Atlantic puffins from Røst and Hornøya. These general patterns are supported by recent independent analyses of the recoveries of all Atlantic puffins ringed by the British and Norwegian ringing schemes (Harris 2002, Bakken et al. 2003).

There were striking differences in the recovery rates of birds ringed at the study colonies. For instance, totals of 17462,12759 and 2333 Atlantic puffins ringed on Røst, Fair Isle and Hornøya, respectively, had
Table 2. Patterns of spatial correlations among local SST time series. Pearson correlation coefficients are given for period covered by longest survival-rate time series (1984 to 2000) and (in parentheses) for period 1990 to 2001 covered by all time series of survival. ${ }^{*}$ Significant at $5 \%$; ${ }^{* *}$ significant at $1 \%$

\begin{tabular}{|c|c|c|c|c|}
\hline Area & Isle of May & Fair Isle & Røst & Hornøya \\
\hline \multicolumn{5}{|c|}{ January to May } \\
\hline Skomer & $0.73^{* *}\left(0.70^{*}\right)$ & $0.68^{* *}\left(0.67^{*}\right)$ & $0.44 \quad(0.08)$ & $-0.29(-0.43)$ \\
\hline Isle of May & & $0.86^{* *}\left(0.91^{* *}\right)$ & $0.58^{*}\left(0.64^{*}\right)$ & $-0.35(-0.30)$ \\
\hline Fair Isle & & & $0.57^{*}\left(0.67^{*}\right)$ & $-0.39(-0.36)$ \\
\hline Røst & & & & $0.15 \quad(0.09)$ \\
\hline \multicolumn{5}{|l|}{ May to July } \\
\hline Skomer & $0.65^{* *}\left(0.66^{*}\right)$ & $0.26 \quad(0.45)$ & $0.42 \quad(0.46)$ & $-0.24(-0.37)$ \\
\hline Isle of May & & $0.75^{* *}(0.53)$ & $0.53^{*}\left(0.69^{* *}\right)$ & $-0.29(-0.29)$ \\
\hline Fair Isle & & & $0.48^{*}\left(0.64^{* *}\right)$ & $-0.04 \quad(0.09)$ \\
\hline Røst & & & & $-0.05(-0.02)$ \\
\hline
\end{tabular}


Strong correlations were found among the 3 southernmost colonies (Skomer, Isle of May and Fair Isle) and among the 3 colonies at intermediate latitudes (Isle of May, Fair Isle and Røst) (Table 2, Fig. 2). SST around Hornøya, in the Barents Sea, showed no significant correlation with SSTs around the other colonies.

\section{Adult survival reference-models}

The model selected for Skomer, Fair Isle and Isle of May was $\Phi(y) p\left(a_{3}+y\right)$. For Hornøya, the model $\Phi(\mathrm{cst})$ $p\left(a_{3}+y\right)$ was retained. Finally, for Røst, model $\Phi(y)$

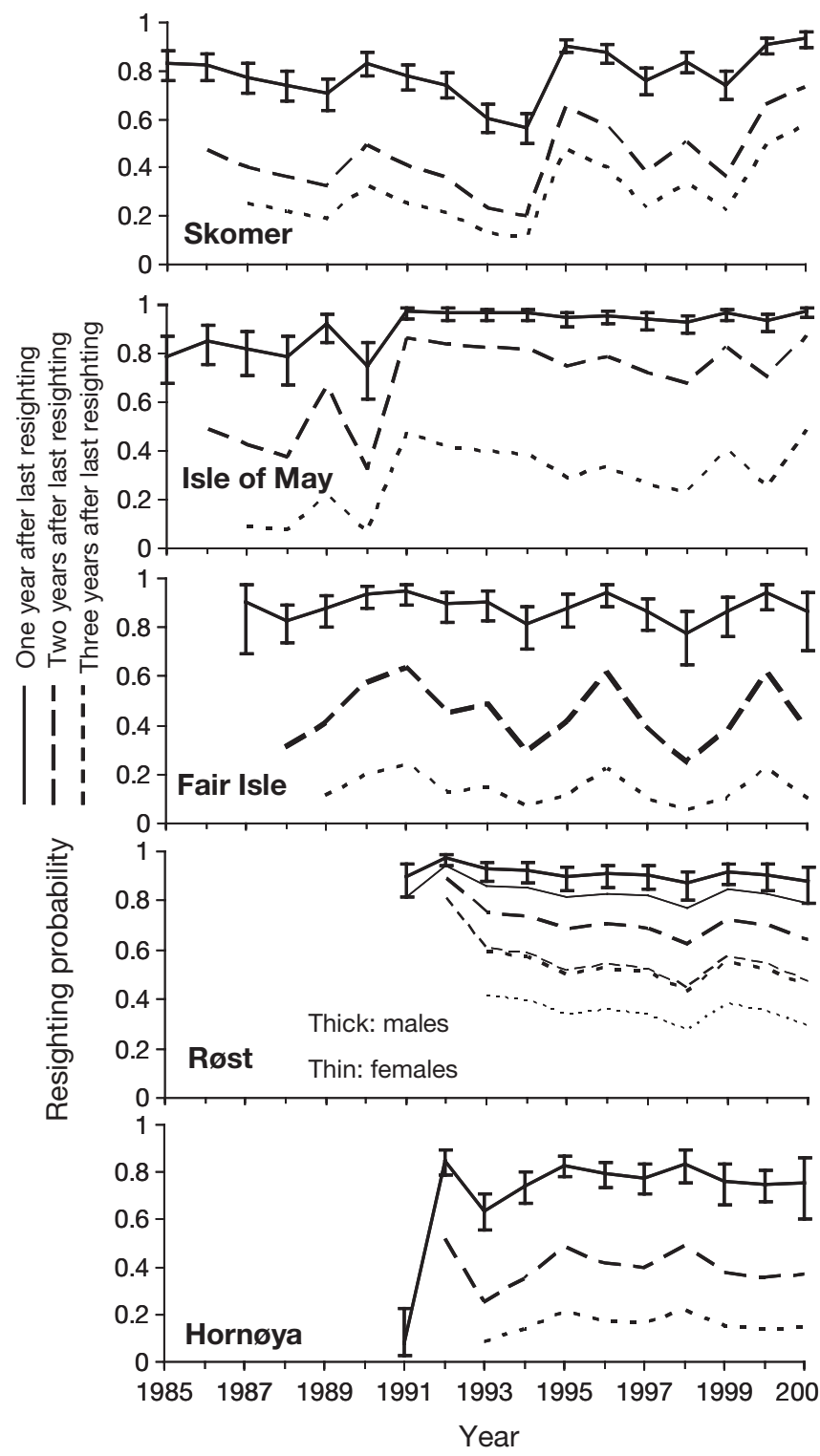

Fig. 3. Fratercula arctica. Annual variation in resighting probabilities in the 5 colonies 1, 2 and 3 yr after last re-sighting; $\pm 95 \%$ CI shown for 1 yr data

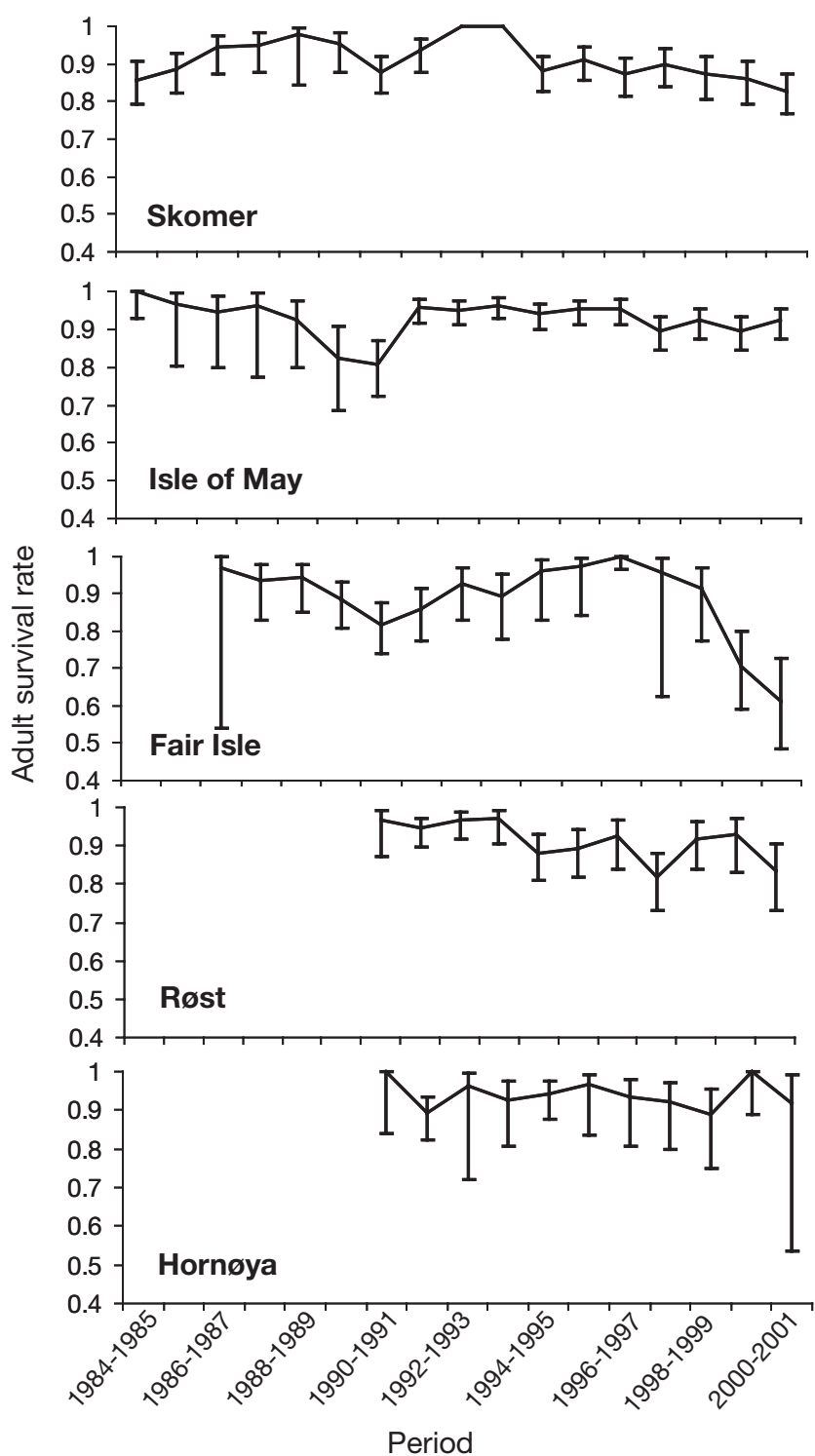

Fig. 4. Fratercula arctica. Annual estimates $( \pm 95 \%$ CI $)$ of survival rates in the 5 colonies

$p\left(a_{3}+y+\right.$ sex $)$ was retained. For Røst, resighting probability of females was slightly lower than that of males. This sex effect was not detected in the Isle of May colony, where information on the sex of individuals was also available. Since sex did not appear to influence survival significantly, it is not discussed further. For all colonies 3 'age since last resighting' classes and a year effect were thus retained in the modelling of resighting probability. Probability of being seen 2 yr after last resighting was lower than after $1 \mathrm{yr}$, and the probability after more than $2 \mathrm{yr}$ after last resighting was lower still (Fig. 3). Except for Hornøya, there were significant inter-annual variations in survival (Fig. 4, see also Tables 3 \& 5). 
Table 3. Fratercula arctica. Adult survival rate means (to the nearest $0.005 \pm \mathrm{SE}$ ) and process standard deviation (95\% CI) for each colony and covariation among colony time series (period 1990 to 2001 given in second line)

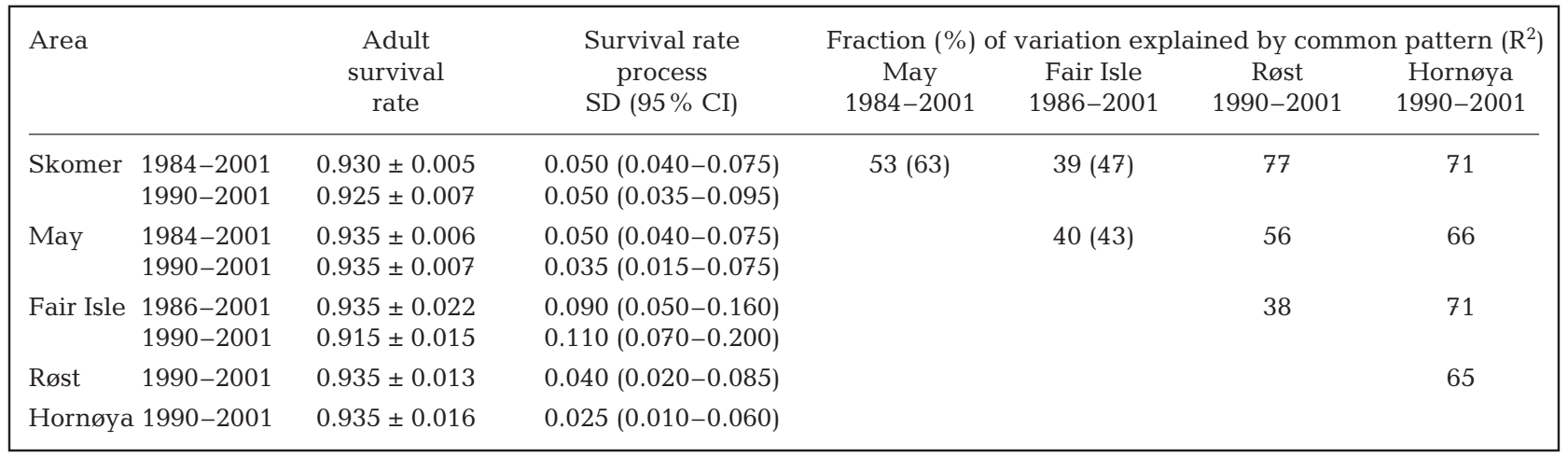

\section{Adult survival averages and variability}

Mean survival rate estimates over the maximum time periods showed very little variation among colonies $(0.930 \pm$ SE 0.005 for Skomer, $0.935 \pm 0.006$ for the Isle of May, $0.935 \pm 0.022$ for Fair Isle, $0.935 \pm 0.013$ for Røst, and $0.935 \pm 0.016$ for Hornøya) and none of the inter-colony differences were significant ( $Z$-values 0 to 1.12 for comparison of the logit of mean survival; corresponding p-values 1 to 0.26 ). The survival rate at Skomer over the common time period 1990 to 2001 was slightly lower at $0.925 \pm 0.007$ (Table 3 ). The likelihood optimisation procedure converged towards an unrealistic estimate of mean survival rate $(=1)$ for Fair Isle for the period 1990 to 2001. By allowing the estimate for the period 1996 to 1997 to differ from the mean survival over the periods 1990 to 2001, a more realistic estimate $(0.915 \pm 0.015)$ was obtained. We retained this value as an estimate of the mean survival rate at this colony for the period 1990 to 2001. As for Skomer, it is slightly lower than the estimate of mean survival rate over the maximum time period (see above). Again none of the inter-colony differences were significant over the period 1990 to 2001 (Z-values 0 to 0.88 ; $\mathrm{p}$-values 1 to 0.38 ). Temporal variability in survival rate (expressed as the estimate of survival standard deviation $\hat{\sigma}$, the square root of the estimate of the survival variance $\hat{\sigma}^{2}$ ) showed more variation among colonies, being lowest (0.025) for Hornøya and highest (0.09) for Fair Isle (Table 3, Fig. 4).

\section{Temporal variation in adult survival rates: patterns of similarity between colonies}

The pattern of similarity between time series of adult survival rates in the colonies (as reflected by the $\mathrm{R}^{2}$ of a common pattern of variation model) did not differ substantially according to whether one considered the whole period of overlap between survival time series in each pair of colonies or only the period 1990 to 2001 covered by all the survival time series (Table 3 ). The highest $\mathrm{R}^{2}$ were found for the pairs Røst/Skomer, Hornøya/Skomer and Hornøya/Fair Isle, colonies some $2000 \mathrm{~km}$ apart that did not show any overlap in the locations of winter recoveries (see earlier subsection 'Winter dispersal'). Comparison of Hornøya with other colonies yielded consistently high fractions of temporal variation accounted for by a common pattern $\left(\mathrm{R}^{2}\right.$ ranging from 65 to $71 \%$ ), while comparison of Fair Isle with other colonies yielded consistently lower $\mathrm{R}^{2}$ (38 to $47 \%$, excluding the comparison with Hornøya); this was at least partly due to the sharp decline in survival in the later years.

\section{Temporal variation in survival probabilities: correlations with environmental factors}

For Skomer, Fair Isle, Røst and Hornøya, local SST in January to May of Year Y-1 explained at least $20 \%$ of the variation in adult survival between the breeding season of Year Y and that of Year Y+1 (Tables 4 \& 5, Fig. 5). In contrast, local SST in May to July of Year Y was more important for Atlantic puffins on the Isle of May, explaining $26 \%$ of the variation in adult survival between the breeding season of Year Y and that of Year Y+1. The influence of increased SST was positive for Atlantic puffins on Røst but negative for the birds at the other colonies. In addition to the effect of SST, wNAO explained more than $20 \%$ of the variation in adult survival at Skomer and Hornøya, having a positive effect on Skomer birds in the same winter and a negative effect on Hornøya puffins 2 yr later (Tables 4 \& 5, Fig. 5).

All the relationships detected between environmental factors and survival were significant at the $5 \%$ level except for those relating to Hornøya. This was 
probably due to the low variability of adult survival at this colony. Furthermore, a graphical examination of the relationships between climatic factors and survival of Hornøya birds (Fig. 5) revealed that the 4 last estimates of the survival time series were outliers in the relationships with SST and wNAO. Hence, the relationships detected for Hornøya must be considered with caution.

\section{DISCUSSION}

The estimated mean annual survival rates of adult Atlantic puffins of 0.930 to 0.935 were high, although slightly lower than estimates of 0.95 and 0.975 for Skomer and the Isle of May, respectively, during the 1970s (Ashcroft 1979, Harris et al. 1997) and of 0.95 for an introduced population in the western Atlantic

Table 4. Fratercula arctica. Selection of climatic/oceanographic covariates influencing survival between Breeding Season Y and $\mathrm{Y}+1$. Step 1: among those covariates whose inclusion in model resulted in a $\mathrm{R}^{2} \geq 20 \%$, that leading to largest $\mathrm{R}^{2}$ was selected; Step 2: that covariate whose inclusion in model increased $\mathrm{R}^{2}$ by largest extent, and by at least $20 \%$ relative to model arising from Step 1, was selected. wNAO: winter North Atlantic Oscillation

\begin{tabular}{|c|c|c|c|c|c|c|c|c|c|c|}
\hline \multirow{2}{*}{ Breeding season } & \multicolumn{2}{|c|}{ Skomer } & \multicolumn{2}{|c|}{ Fair Isle } & \multicolumn{2}{|c|}{ Isle of May } & \multicolumn{2}{|c|}{ Røst } & \multicolumn{2}{|c|}{ Hornøya } \\
\hline & $\mathrm{R}^{2}(\%)$ & $\mathrm{p}$ & $\mathrm{R}^{2}(\%)$ & $\mathrm{p}$ & $\mathrm{R}^{2}(\%)$ & $\mathrm{p}$ & $\mathrm{R}^{2}(\%)$ & $\mathrm{p}$ & $\mathrm{R}^{2}(\%)$ & $\mathrm{p}$ \\
\hline \multicolumn{11}{|l|}{ Step 1} \\
\hline SST January Y-1 to May Y-1 & 13 & 0.16 & 49 & 0.004 & 9 & 0.24 & 40 & 0.04 & 19 & 0.17 \\
\hline SST January Y to May Y & 4 & 0.41 & 20 & 0.09 & 20 & 0.07 & 28 & 0.09 & 4 & 0.54 \\
\hline SST May Y to July Y & 0 & 0.85 & 16 & 0.14 & 26 & 0.04 & 18 & 0.19 & 1 & 0.34 \\
\hline wNAO December Y to 2 to March Y-1 & 0 & 0.78 & 26 & 0.05 & 1 & 0.7 & 31 & 0.07 & 11 & 0.3 \\
\hline wNAO December Y to 1 March Y & 7 & 0.31 & 25 & 0.06 & 12 & 0.17 & 4 & 0.57 & 7 & 0.42 \\
\hline wNAO December Y to March Y+1 & 20 & 0.07 & 8 & 0.3 & 2 & 0.55 & 35 & 0.05 & 10 & 0.34 \\
\hline \multicolumn{11}{|l|}{ Step 2} \\
\hline SST January Y-1 to May Y-1 & 45 & 0.02 & & & 28 & 0.51 & & & & \\
\hline SST January Y to May Y & 26 & 0.29 & 54 & 0.27 & 27 & 0.64 & 46 & 0.36 & 22 & 0.57 \\
\hline SST May Y to July Y & 21 & 0.76 & 53 & 0.32 & & & 41 & 0.66 & 22 & 0.56 \\
\hline wNAO December Y-2 to March Y-1 & 23 & 0.48 & 49 & 0.84 & 28 & 0.51 & 50 & 0.24 & 43 & 0.1 \\
\hline wNAO December Y-1 to March Y & 22 & 0.56 & 61 & 0.08 & 28 & 0.59 & 40 & 0.75 & 19 & 0.81 \\
\hline wNAO December Y to March Y+1 & & & 49 & 0.9 & 28 & 0.56 & 42 & 0.59 & 23 & \\
\hline
\end{tabular}

Table 5. Fratercula arctica. Final model for survival between Breeding Season Y and Y+1. Relationship between environmental covariates and survival described by estimate of the slope, $95 \%$ confidence interval for the slope (in parentheses) and ANODEV $\mathrm{p}$-value for the relationship. AICc (Akaike's information criterion modified for each data sparseness) of constant and fully timedependent models are given for comparison with final covariate model. wNAO: winter North Atlantic Oscillation

\begin{tabular}{|c|c|c|c|c|c|}
\hline & $\begin{array}{c}\text { Skomer } \\
1984-2000\end{array}$ & $\begin{array}{l}\text { Isle of May } \\
1984-2000\end{array}$ & $\begin{array}{c}\text { Fair Isle } \\
\text { 1986-2000 }\end{array}$ & $\begin{array}{c}\text { Røst } \\
1990-2000\end{array}$ & $\begin{array}{c}\text { Hornøya } \\
1990-2000\end{array}$ \\
\hline AICc constant survival model & 4867.1 & 2875.6 & 2258.1 & 2494.3 & 3978.6 \\
\hline AICc fully time dependent survival model & 4854.4 & 2856.6 & 2230.1 & 2481.8 & 3988.8 \\
\hline AICc of the final covariate survival model & 4850.8 & 2864.2 & 2232.1 & 2483.3 & 3978.3 \\
\hline $\mathrm{R}^{2}$ associated to the covariate model & 45 & 26 & 49 & 40 & 43 \\
\hline SST January Y-1 to May Y-1 & $\begin{array}{c}-0.37 \\
(-0.54 ;-0.20) \\
p=0.025\end{array}$ & & $\begin{array}{c}-0.68 \\
(-0.96 ;-0.40) \\
p=0.004\end{array}$ & $\begin{array}{c}0.46 \\
(0.21 ; 0.72) \\
p=0.04\end{array}$ & $\begin{array}{c}-1.16 \\
(-3.00 ; 0.68) \\
p=0.07\end{array}$ \\
\hline \multicolumn{6}{|l|}{ SST January Y to May Y } \\
\hline SST May Y to July Y & & $\begin{array}{c}-0.36 \\
(-0.55 ;-0.16) \\
p=0.04\end{array}$ & & & \\
\hline wNAO December Y-2 to March Y-1 & & & & & $\begin{array}{c}-1.1 \\
(-3.20 ; 1.00) \\
p=0.1\end{array}$ \\
\hline \multicolumn{6}{|l|}{ wNAO December Y-1 to March Y } \\
\hline wNAO December Y to March Y+1 & $\begin{array}{c}0.32 \\
(0.19 ; 0.46) \\
p=0.01\end{array}$ & & & & \\
\hline
\end{tabular}


(Breton et al. in press). Despite highly contrasting patterns of breeding population change among the colonies, adult survival was remarkably consistent, giving no support to the hypothesis that survival was an important demographical driver. There were, however, marked differences between colonies in the inter-annual variability of survival rates for which we have no satisfactory explanation. Breeding success (lagged $5 \mathrm{yr}$ to cover time between fledging and becoming adult) was generally high in the 4 stable or
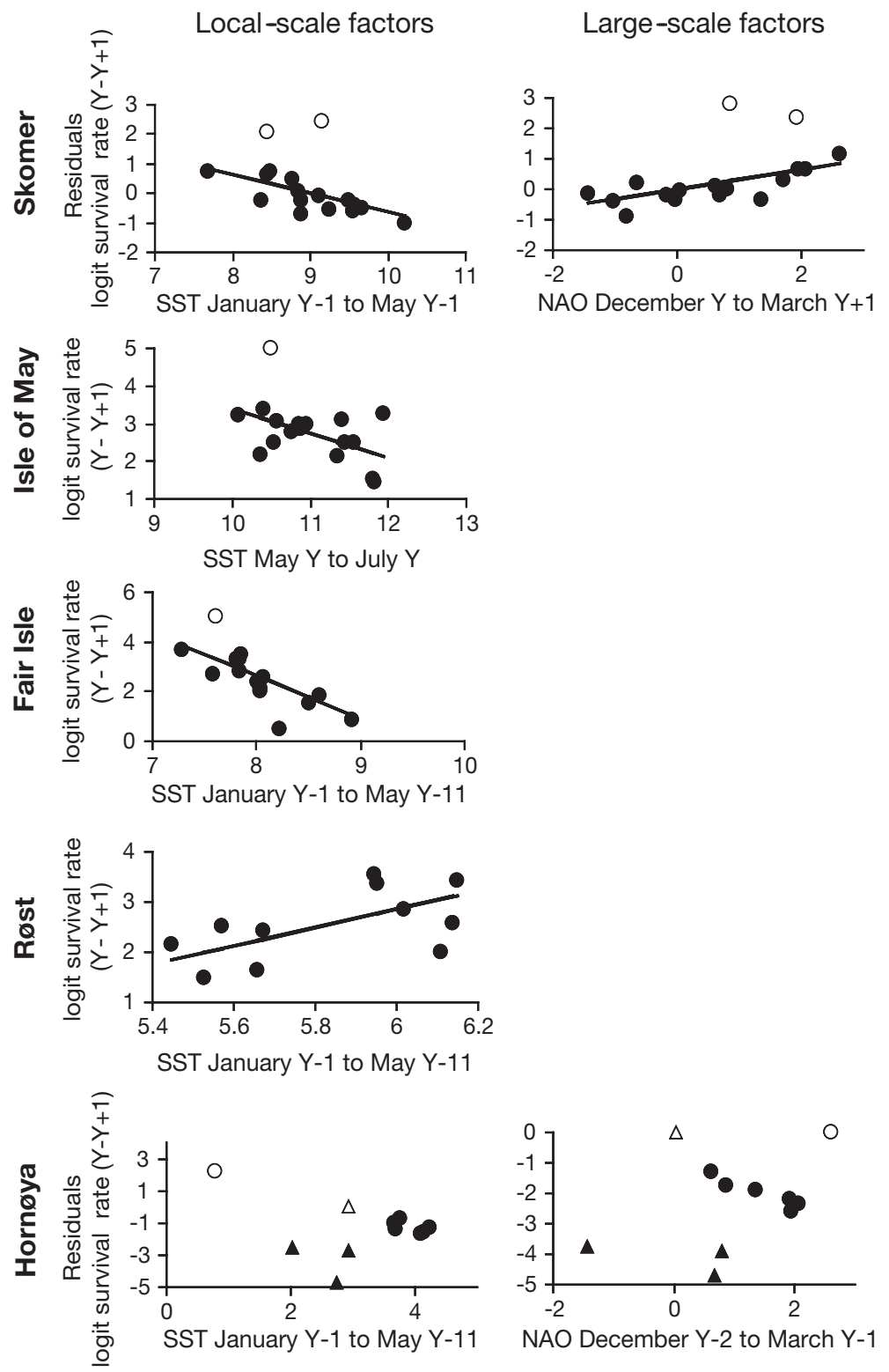

Fig. 5. Fratercula arctica. Relationship between logit survival rate and environmental variables (SST: sea surface temperature; NAO: North Atlantic Oscillation) for the 5 colonies. (O) Survival estimates at upper boundary $(=1)$ that must be considered with caution; $(\Delta)$ estimates for last 4 time intervals of time series at Hornøya (see 'Discussion' for Hornøya results) increasing colonies, averaging 0.72 to 0.85 young fledging per pair laying (Table 1). In contrast, Atlantic puffins in the decreasing colony at Røst had a much lower, and more variable, average success of 0.42 young fledging per pair that hatched a young. Since many breeding attempts fail during incubation (Harris 1984), overall breeding success at Røst will have been substantially lower than this. Thus it seems likely that recruitment (the integration of breeding success, survival to breeding age and natal dispersal) rather than adult survival is underlying variation in growth rate among colonies of Atlantic puffins.

Although care is needed in the interpretation of recoveries of ringed seabirds that spend most of their lives in the open ocean, where birds that die have only a very small chance of being found, the distributions of recoveries during the winter of birds from the study areas showed very marked patterns. Adults from the Isle of May were mainly within the North Sea, whereas those from Skomer and Fair Isle dispersed widely in the Atlantic west of Britain, France and Iberia, with some entering the Mediterranean, and those from the 2 Norwegian colonies had a much more northerly distribution. Hence, if environmental conditions over the wintering areas were the main driver of variation in Atlantic puffin survival, the pattern of covariation in adult survival would be expected to be structured in 3 clusters (Fair Isle and Skomer/Isle of May/Røst and Hornøya). This was not the case. Under the hypothesis that oceanographic or weather conditions in winter strongly influenced Atlantic puffin adult survival, we would also have expected to detect unlagged effects of the wNAO, because this large-scale climate index reflects variation in weather and oceanographic conditions in winter over most NE Atlantic regions (Becker \& Pauly 1996, Hurrell et al. 2003). Such effect was detected for only 1 colony (Skomer), suggesting that oceanographic and weather conditions of the wintering areas have little influence on Atlantic puffin survival. The diet of the Atlantic puffin outside the breeding season is largely unknown, so the possibility that food abundance in the wintering areas influences the survival of adult Atlantic puffins cannot be ruled out. However, the mismatch between the pattern of spatial overlap between winter recoveries of adults from the different study colonies on the one hand and the pattern of covariation in adult survival among colonies on the other hand suggests that food abundance in the wintering areas is unlikely to account for much of the variation in survival. 
Whereas we detected an influence of the proxy presumably reflecting oceanographic and weather conditions in the wintering areas (i.e. unlagged wNAO) in only 1 out of 5 colonies, oceanographic factors in the vicinity of the breeding colonies correlated with adult survival in all colonies. Local SST in January to May had a significant effect on survival 2 yr later in 4 out 5 colonies. These relationships probably reflect the importance of the abundance of the main prey during the breeding season (herring for Røst, sandeel and capelin for Hornøya and sandeel for all other colonies). The slopes of the relationships with SST in January to May are compatible with this interpretation, being negative where sandeels and capelin are the main food, and positive where herring are taken. These contrasting relationships might be explained by recruitment in sandeels and capelin decreasing with increasing sea temperature and the reverse being true for herring, where recruitment decreases with increasing sea temperatures (Arnott \& Ruxton 2002, Sætre et al. 2002, Hjermann et al. 2004). In addition to these SST effects, the equally long lagged ( 2 yr) effect of wNAO on survival at Hornøya was also in agreement with the hypothesis that the main prey species at the colony are either the key species affecting adult survival of the Atlantic puffin, or at least that they respond to SST changes in a similar way. Given a sudden food shortage in summer, as not infrequently occurs on Røst, there is no reason to suppose that adults would remain in the area and die of starvation. In all probability a combination of winter and summer food availability influences the survival of adult seabird, since individuals entering the winter in poor condition are more likely to die than those in good condition.

The relationship between SST and adult survival on the Isle of May differed from that detected in the other colonies. Here, SST during the breeding season had the strongest effect on survival during the subsequent year, suggesting a more direct influence of oceanographic conditions during the breeding season on food and hence survival the following winter. It is, however, difficult to separate this effect from that of SST in January to May of the same year. The 2 measures were highly autocorrelated (Pearson correlation coefficient $\mathrm{r}=0.84$ ) and while SST in May to July showed the strongest correlation with adult survival $\left(\mathrm{R}^{2}=26 \%\right.$; Table 4), SST in January to May of the same year also explained a substantial fraction of the variation in adult survival $\left(\mathrm{R}^{2}=20 \%\right.$; Table 4$)$. Thus again it may well have been a trophic response to food abundance, but seemingly the birds from Isle of May were most sensitive to the availability of 0 - and 1-group fishes (mainly sandeels in the North Sea) while those from the other colonies probably depended more heavily on 1- and 2-group fishes.
Although the results of the pattern-oriented analysis presented here have to be interpreted with caution (especially for the colony of Hornøya, where little variation in adult survival was detected), the local SST effects detected suggest that food abundance during, or possibly soon after, reproduction influences the survival of adult Atlantic puffins. A similar conclusion has been reached for 2 other sandeel consumers, the black-legged kittiwake Rissa tridactyla and the great skua Catharacta skua, in Shetland (Oro \& Furness 2002, Ratcliffe et al. 2002). The Atlantic puffin, blacklegged kittiwake and great skua are all pelagic outside the breeding season. The coefficient of determination of our model that includes all selected covariates ranged from 26 to $49 \%$. The Atlantic puffin is the the most numerous seabird in the western Palearctic (Mitchell et al. 2004), but until we obtain more information from process-oriented studies outside the breeding season, we are unlikely to greatly improve our understanding of the factors influencing the survival of this pelagic species.

Acknowledgements. We thank the many people who helped collect the data used in these analyses; the British Trust for Ornithology and the Norwegian Ringing Centre for supplying ringing totals and recoveries; R. Barrett for allowing us to use unpublished data from Hornøya; L. Crespin for considerable help with the analyses; and S. Wanless, M. Frederiksen, C. M. Perrins and 4 anonymous reviewers for improving the manuscript with criticisms. Studies on Skomer, Fair Isle and the Isle of May were supported by the Joint Nature Conservation Committee, those on Røst and Hornøya by the Norwegian Directorate for Nature Management (DN) and the Environmental Protection Departments of the County Governors in Nordland, Troms and Finnmark. N. C. Stenseth and his EcoClim project helped initiate this analysis.

\section{LITERATURE CITED}

Anker-Nilssen T (1992) Food supply as a determinant of reproduction and population development in Norwegian puffins Fratercula arctica. Dr Sci thesis, University of Trondheim

Anker-Nilssen T, Aarvak T (2004) The population ecology of the Atlantic puffin at Røst. Status after the breeding season 2003. NINA Oppdragsmeld 809:1-44

Anker-Nilssen T, Brøseth H (1998) Long-term studies of the breeding biology of puffins at Røst. An update with results from 1995-97. NINA Fagrapp 32:1-46

Anker-Nilssen T, Øyan HS (1995) Long-term studies of the breeding biology of puffins at Røst. NINA Fagrapp 15: $1-48$

Anker-Nilssen T, Røstad OW (1993) Census and monitoring of puffins Fratercula arctica on Røst, N Norway, 1979-1988. Ornis Scand 24:1-9

Anker-Nilssen T, Tatarinkova IP (2000) Atlantic puffin Fratercula arctica. In: Anker-Nilssen T, Bakken V, Strøm H, Golovkin AN, Bianki VV, Tatarinkova IP (eds) The status of marine birds breeding in the Barents Sea region. Nor Polarinst Rapp Ser 113:137-143 
Arnott SA, Ruxton GD (2002) Sandeel recruitment in the North Sea: demographic, climatic and trophic effects. Mar Ecol Prog Ser 238:199-210

Ashcroft RE (1979) Survival rates and breeding biology of puffins on Skomer Island, Wales. Ornis scand 10:100-110

Attril M, Power M (2002) Climatic influence on a marine fish assemblage. Nature 417:275-278

Bakken V, Runde O, Tjørve E (2003) Norsk ringmerkingsatlas (Norwegian ringing atlas), Vol 1. Stavanger Museum, Stavanger

Barrett RT (1983) Seabird research on Hornøy, East Finnmark with notes from Nordland, Troms and West Finnmark 1980-1983. A preliminary report. Tromsø University Museum, Tromsø

Barrett RT (2001) Monitoring the Atlantic puffin Fratercula arctica, common guillemot Uria aalge and black-legged kittiwake Rissa tridactyla breeding populations on Hornøya, northeast Norway, 1980-2000. Fauna Norv Ser 21:1-10

Barrett RT (2002) Atlantic puffin Fratercula arctica and common guillemot Uria aalge chick diet and growth as indicators of fish stocks in the Barents Sea. Mar Ecol Prog Ser 230:275-287

Becker GA, Pauly M (1996) Sea surface temperature changes in the North Sea and their causes. ICES J Mar Sci 53: 887-898

Breton AR, Diamond AW, Kress SW (in press) Adult survival from two Atlantic puffin (Fratercula arctica) colonies in the Gulf of Maine. Auk

Burnham KP, Anderson DR (1998) Model selection and inference. A practical information-theoretic approach. Springer-Verlag, New York

Cam E, Hines JE, Monnat JY, Nichols JD, Danchin E (1998) Are adult nonbreeders prudent parents? The kittiwake model. Ecology 79:2917-2930

Choquet R, Reboulet AM, Pradel R, Lebreton JD (2001) U-care (utilities - capture-recapture) user's guide. CNRS (Centre National de la Recherche Scientifique), Montpellier

Croxall JP, Rothery P (1991) Population regulation of seabirds: implications of their demography for conservation. In: Perrins CM, Lebreton JD, Hirons GJM (eds) Bird population studies: relevance to conservation and management. Oxford University Press, Oxford, p 272-295

Durant JM, Anker-Nilssen T, Stenseth NC (2003) Trophic interactions and climate change: the Atlantic puffin as an example. Proc R Soc Lond Ser B 270:1461-1466

Edwards M, Beaugrand G, Reid PC, Rowden AA, Jones MB (2002) Ocean climate anomalies and the ecology of the North Sea. Mar Ecol Prog Ser 239:1-10

Gould WR, Nichols JD (1988) Estimation of temporal variability of survival in animal populations. Ecology 79 : $2531-2538$

Harris MP (1984) The puffin. T \& AD Poyser, Calton

Harris MP (2002) Atlantic puffin (puffin) Fratercula arctica. In: Wernham CV, Toms M, Marchant JH, Clark JA, Siriwardena GM, Baillie SR (eds) The migration atlas; movements of the birds of Britain and Ireland. T \& AD Poyser, London, p 407-409

Harris MP, Wanless S (2004) The Atlantic puffin Fratercula arctica. In: Mitchell IP, Newton SF, Ratcliffe N, Dunn TE (eds) Seabird populations in Britain and Ireland. T \& AD Poyser, London, p 392-406

Harris MP, Freeman SN, Wanless S, Morgan BJT, Wernham CV (1997) Factors influencing the survival of puffins Fratercula arctica at a North Sea colony over a 20 -year period. J Avian Biol 28:287-295

Harris MP, Wanless S, Murray S, Leitch A, Wilson LJ (2003)
Counts of Atlantic puffins Fratercula arctica in the Firth of Forth, south-east Scotland in 2003. Atl Seabirds 5: $101-110$

Hjermann DØ, Stenseth NC, Ottersen G (2004) Indirect climatic forcing of the Barents Sea capelin: a cohort effect. Mar Ecol Prog Ser 273:229-238

Hurrell JW, Kushnir Y, Ottersen G, Visbeck M (2003) The North Atlantic Oscillation: climate significance and environmental impact. Geophys Monogr 134:1-279

Lebreton JD, Burnham KP, Clobert J, Anderson DR (1992) Modelling survival and testing biological hypotheses using marked animals: a unified approach with case studies. Ecol Monogr 62:37-118

Mitchell PI, Newton SF, Ratcliffe N, Dunn TE (2004) Seabird populations of Britain and Ireland. Results of the seabird 2000 census (1998-2002). T \& AD Poyser, London

Myrberget S (1973) Ringing of shags and puffins at Røst, north Norway. Sterna (Stavanger) 12:307-315

Nur N, Sydeman WJ (2000) Survival, breeding probablity and reproductive success in relation to population dynamics of Brandt's cormorants Phalacrocorax penicillatus. Bird Study 46:S92-103

Oro D, Furness RW (2002) Influences of food availability and predation on survival of kittiwakes. Ecology 83:2516-2528

Ottersen G, Planque B, Belgrano A, Post E, Reid PC, Stenseth NC (2001) Ecological effects of the North Atlantic Oscillation. Oecologia 128:1-14

Planque B, Taylor AH (1998) Long-term changes in zooplankton and the climate of the North Atlantic. ICES J Mar Sci 55:644-654

Pradel R (1993) Flexibility in survival analysis from recapture data: handling trap-dependence. In: Lebreton JD, North PM (eds) Marked individuals in the study of bird populations. Birkhauser Verlag, Basel, p 29-37

Ratcliffe N, Catry P, Hamer KC, Klomp NI, Furness RW (2002) The effect of age and year on the survival of breeding adult great skuas Catharacta skua in Shetland. Ibis 144: 384-392

Reynolds RW, Rayner NA, Smith TM, Stokes DC, Wang W (2002) An improved in situ and satellite SST analysis for climate. J Climate 15:1609-1625

Sætre R, Toresen R, Anker-Nilssen T (2002) Factors affecting the recruitment variability of the Norwegian springspawning herring (Clupea harengus L.). ICES J Mar Sci 59:725-736

SAS (1999) SAS property software release 8.02. SAS Institute, Cary, NJ

Skalski JR, Hoffmann A, Smith SG (1993) Testing the significance of individual- and cohort-level covariates in animal survival studies. In: Lebreton JD, North PM (eds) Marked individuals in the study of bird populations. Birkhauser Verlag, Basel, p 9-28

Stone CJ, Webb A, Barton C, Ratcliffe N, Reed TC, Tasker ML, Camphuysen CJ, Pienkowski MW (1995) An atlas of seabird distribution in north-west European waters. Joint Nature Conservation Committee, Peterborough

Toresen R, Østvedt OJ (2000) Variation in abundance of Norwegian spring-spawning herring (Clupea harengus, Clupeidae) throughout the 20th century and the influence of climatic fluctuations. Fish Fish Ser 2000:231-256

White GC, Burnham KP (1999) Program MARK: survival estimation from populations of marked animals. Bird Study 46 (Suppl):120-139

Wooller RD, Bradley JS, Skira IJ, Serventy DL (1990) Reproductive success of short-tailed shearwaters Puffinus tenuirostris in relation to their age and breeding experience. J Anim Ecol 59:161-170 
Appendix 1. Fratercula arctica. M-arrays for the 5 study colonies. N: no. of individuals encountered (initial capture or resighting). Data on males and females on Røst shown separately because the CMR model selected for describing Røst data included sex effect on recapture probability

\begin{tabular}{|c|c|c|c|c|c|c|c|c|c|c|c|c|c|c|c|c|c|c|c|}
\hline \multirow[t]{2}{*}{ Year } & \multirow[t]{2}{*}{$\mathrm{N}$} & \multicolumn{18}{|c|}{ First subsequent resightings } \\
\hline & & 1985 & 1986 & 1987 & 1988 & 1989 & 1990 & 1991 & 1992 & 1993 & 1994 & 1995 & 1996 & 1997 & 1998 & 1999 & 2000 & 2001 & 2002 \\
\hline \multicolumn{20}{|l|}{ Skomer } \\
\hline 1984 & 198 & 141 & 9 & 2 & 0 & 3 & 3 & 4 & 1 & 0 & 1 & 0 & 0 & 0 & 0 & 0 & 0 & 0 & 0 \\
\hline 1985 & 191 & & 142 & 8 & 0 & 6 & 4 & 0 & 0 & 0 & 0 & 1 & 1 & 0 & 1 & 0 & 0 & 1 & 0 \\
\hline 1986 & 176 & & & 133 & 12 & 2 & 7 & 1 & 0 & 2 & 0 & 1 & 1 & 1 & 0 & 0 & 0 & 0 & 0 \\
\hline 1987 & 169 & & & & 125 & 14 & 7 & 2 & 2 & 0 & 0 & 1 & 0 & 1 & 1 & 0 & 0 & 0 & 1 \\
\hline 1988 & 157 & & & & & 104 & 31 & 4 & $\overline{1}$ & 1 & 1 & 3 & 0 & 0 & 0 & 1 & 0 & 0 & 0 \\
\hline 1989 & 158 & & & & & & 115 & 7 & 4 & 0 & 5 & 7 & 4 & 0 & 0 & 1 & 0 & 1 & 1 \\
\hline 1990 & 239 & & & & & & & 170 & 10 & 3 & 3 & 9 & 1 & 3 & 0 & 2 & 0 & 1 & 0 \\
\hline 1991 & 241 & & & & & & & & 174 & 13 & 5 & 15 & 5 & 1 & 1 & 0 & 0 & 2 & 0 \\
\hline 1992 & 219 & & & & & & & & & 135 & 15 & 37 & 13 & 2 & 0 & 1 & 1 & 0 & 1 \\
\hline 1993 & 172 & & & & & & & & & & 96 & 48 & 11 & 2 & 1 & 0 & 1 & 0 & 0 \\
\hline 1994 & 141 & & & & & & & & & & & 100 & 11 & 5 & 3 & 0 & 0 & 0 & 0 \\
\hline 1995 & 248 & & & & & & & & & & & & 194 & 8 & 5 & 3 & 4 & 2 & 1 \\
\hline 1996 & 262 & & & & & & & & & & & & & 172 & 31 & 3 & 7 & 2 & 1 \\
\hline 1997 & 211 & & & & & & & & & & & & & & 158 & 8 & 8 & 4 & 4 \\
\hline 1998 & 221 & & & & & & & & & & & & & & & 145 & 30 & 5 & 3 \\
\hline 1999 & 168 & & & & & & & & & & & & & & & & 132 & 7 & 3 \\
\hline 2000 & 203 & & & & & & & & & & & & & & & & & 158 & 8 \\
\hline 2001 & 190 & & & & & & & & & & & & & & & & & & 160 \\
\hline Isle of $\mathrm{N}$ & & & & & & & & & & & & & & & & & & & \\
\hline 1984 & 71 & 56 & 6 & 2 & 1 & 1 & 0 & 1 & 0 & 1 & 0 & 0 & 0 & 0 & 0 & 0 & 0 & 0 & 0 \\
\hline 1985 & 75 & & 63 & 3 & 0 & 1 & 0 & 1 & 0 & 1 & 0 & 0 & 0 & 0 & 0 & 1 & 0 & 0 & 0 \\
\hline 1986 & 73 & & & 56 & 3 & 4 & 1 & 0 & 2 & 0 & 0 & 0 & 0 & 0 & 0 & 0 & 0 & 0 & 0 \\
\hline 1987 & 64 & & & & 50 & 6 & 0 & 0 & 1 & 2 & 0 & 0 & 0 & 0 & 0 & 0 & 0 & 0 & 0 \\
\hline 1988 & 61 & & & & & 51 & 3 & 1 & 0 & 0 & 0 & 0 & 0 & 0 & 0 & 0 & 0 & 0 & 0 \\
\hline 1989 & 63 & & & & & & 37 & 12 & 0 & 0 & 0 & 0 & 0 & 0 & 0 & 0 & 0 & 0 & 0 \\
\hline 1990 & 113 & & & & & & & 90 & 1 & 0 & 0 & 0 & 0 & 0 & 0 & 0 & 0 & 0 & 0 \\
\hline 1991 & 197 & & & & & & & & 183 & 2 & 0 & 2 & 1 & 0 & 0 & 0 & 0 & 0 & 0 \\
\hline 1992 & 215 & & & & & & & & & 198 & 6 & 0 & 0 & 0 & 0 & 0 & 0 & 0 & 0 \\
\hline 1993 & 225 & & & & & & & & & & 210 & 6 & 0 & 0 & 0 & 0 & 0 & 0 & 0 \\
\hline 1994 & 221 & & & & & & & & & & & 195 & 11 & 0 & 1 & 0 & 0 & 0 & 0 \\
\hline 1995 & 209 & & & & & & & & & & & & 189 & 5 & 1 & 1 & 0 & 1 & 1 \\
\hline 1996 & 220 & & & & & & & & & & & & & 200 & 7 & 1 & 0 & 0 & 0 \\
\hline 1997 & 218 & & & & & & & & & & & & & & 180 & 13 & 0 & 0 & 1 \\
\hline 1998 & 197 & & & & & & & & & & & & & & & 174 & 5 & 1 & 1 \\
\hline 1999 & 209 & & & & & & & & & & & & & & & & 176 & 9 & 1 \\
\hline 2000 & 190 & & & & & & & & & & & & & & & & & 172 & 3 \\
\hline 2001 & 195 & & & & & & & & & & & & & & & & & & 163 \\
\hline Fair Isle & & & & & & & & & & & & & & & & & & & \\
\hline 1986 & 33 & & & 29 & 1 & 0 & 0 & 1 & 0 & 0 & 0 & 0 & 0 & 0 & 0 & 0 & 0 & 0 & 0 \\
\hline 1987 & 140 & & & & 108 & 8 & 3 & 2 & 0 & 0 & 0 & 0 & 0 & 0 & 3 & 0 & 0 & 0 & 0 \\
\hline 1988 & 123 & & & & & 103 & 8 & 0 & 0 & 0 & 0 & 0 & 1 & 0 & 0 & 0 & 0 & 0 & 0 \\
\hline 1989 & 133 & & & & & & 108 & 7 & 0 & 0 & 0 & 0 & 0 & 0 & 0 & 0 & 0 & 0 & 0 \\
\hline 1990 & 137 & & & & & & & 104 & 2 & 1 & 0 & 0 & 0 & 0 & 1 & 1 & 1 & 0 & 0 \\
\hline 1991 & 127 & & & & & & & & 100 & 2 & 0 & 0 & 0 & 0 & 1 & 3 & 0 & 0 & 0 \\
\hline 1992 & 106 & & & & & & & & & 92 & 0 & 0 & 1 & 1 & 0 & 0 & 1 & 0 & 0 \\
\hline 1993 & 98 & & & & & & & & & & 74 & 5 & 3 & 0 & 0 & 0 & 0 & 1 & 0 \\
\hline 1994 & 78 & & & & & & & & & & & 69 & 4 & 0 & 0 & 0 & 0 & 0 & 0 \\
\hline 1995 & 85 & & & & & & & & & & & & 79 & 1 & 0 & 1 & 0 & 0 & 0 \\
\hline 1996 & 89 & & & & & & & & & & & & & 79 & 4 & 0 & 2 & 1 & 0 \\
\hline 1997 & 85 & & & & & & & & & & & & & & 58 & 10 & 2 & 0 & 2 \\
\hline 1998 & 91 & & & & & & & & & & & & & & & 67 & 7 & 0 & 3 \\
\hline 1999 & 82 & & & & & & & & & & & & & & & & 53 & 1 & 1 \\
\hline 2000 & 81 & & & & & & & & & & & & & & & & & 42 & 4 \\
\hline 2001 & 45 & & & & & & & & & & & & & & & & & & 22 \\
\hline Røst, me & & & & & & & & & & & & & & & & & & & \\
\hline 1990 & 28 & & & & & & & 25 & 1 & 0 & 0 & 0 & 0 & 0 & 0 & 0 & 0 & 0 & 0 \\
\hline 1991 & 75 & & & & & & & & 67 & 2 & 0 & 0 & 1 & 0 & 0 & 0 & 0 & 0 & 0 \\
\hline 1992 & 74 & & & & & & & & & 66 & 5 & 0 & 0 & 0 & 0 & 0 & 0 & 0 & 0 \\
\hline 1993 & 68 & & & & & & & & & & 60 & 0 & 2 & 1 & 0 & 0 & 1 & 0 & 0 \\
\hline 1994 & 66 & & & & & & & & & & & 51 & 5 & 1 & 0 & 0 & 1 & 0 & 0 \\
\hline 1995 & 52 & & & & & & & & & & & & 44 & 3 & 0 & 0 & 0 & 0 & 0 \\
\hline 1996 & 61 & & & & & & & & & & & & & 53 & 2 & 2 & 0 & 0 & 0 \\
\hline 1997 & 61 & & & & & & & & & & & & & & 42 & 6 & 0 & 0 & 0 \\
\hline 1998 & 57 & & & & & & & & & & & & & & & 52 & 1 & 0 & 0 \\
\hline 1999 & 74 & & & & & & & & & & & & & & & & 65 & 2 & 1 \\
\hline 2000 & 74 & & & & & & & & & & & & & & & & & 52 & 5 \\
\hline 2001 & 65 & & & & & & & & & & & & & & & & & & 58 \\
\hline
\end{tabular}


Appendix 1 (continued)

\begin{tabular}{|c|c|c|c|c|c|c|c|c|c|c|c|c|c|c|c|c|c|c|c|}
\hline \multirow[t]{2}{*}{ Year } & \multirow[t]{2}{*}{$\mathrm{N}$} & \multicolumn{18}{|c|}{ First subsequent resightings } \\
\hline & & 1985 & 1986 & 1987 & 1988 & 1989 & 1990 & 1991 & 1992 & 1993 & 1994 & 1995 & 1996 & 1997 & 1998 & 1999 & 2000 & 2001 & 2002 \\
\hline \multicolumn{20}{|c|}{ Røst, females } \\
\hline 1990 & 44 & & & & & & & 34 & 7 & 1 & 1 & 0 & 0 & 0 & 0 & 0 & 0 & 0 & 0 \\
\hline 1991 & 94 & & & & & & & & 86 & 0 & 1 & 1 & 0 & 1 & 0 & 0 & 0 & 0 & 0 \\
\hline 1992 & 107 & & & & & & & & & 92 & 7 & 1 & 1 & 0 & 0 & 1 & 0 & 0 & 0 \\
\hline 1993 & 93 & & & & & & & & & & 77 & 8 & 3 & 1 & 0 & 0 & 0 & 0 & 0 \\
\hline 1994 & 95 & & & & & & & & & & & 72 & 5 & 2 & 0 & 0 & 0 & 0 & 0 \\
\hline 1995 & 82 & & & & & & & & & & & & 58 & 6 & 2 & 0 & 2 & 0 & 1 \\
\hline 1996 & 83 & & & & & & & & & & & & & 60 & 6 & 3 & 1 & 0 & 0 \\
\hline 1997 & 73 & & & & & & & & & & & & & & 49 & 7 & 1 & 1 & 0 \\
\hline 1998 & 84 & & & & & & & & & & & & & & & 60 & 9 & 1 & 2 \\
\hline 1999 & 97 & & & & & & & & & & & & & & & & 70 & 8 & 4 \\
\hline 2000 & 96 & & & & & & & & & & & & & & & & & 67 & 10 \\
\hline 2001 & 91 & & & & & & & & & & & & & & & & & & 73 \\
\hline \multicolumn{20}{|c|}{ Hornøya } \\
\hline 1990 & 37 & & & & & & & 3 & 20 & 1 & 0 & 1 & 2 & 1 & 0 & 0 & 0 & 0 & 0 \\
\hline 1991 & 242 & & & & & & & & 179 & 7 & 2 & 6 & 6 & 0 & 1 & 1 & 1 & 0 & 0 \\
\hline 1992 & 212 & & & & & & & & & 132 & 25 & 8 & 3 & 4 & 4 & 1 & 0 & 0 & 0 \\
\hline 1993 & 145 & & & & & & & & & & 101 & 16 & 2 & 0 & 1 & 1 & 1 & 0 & 0 \\
\hline 1994 & 431 & & & & & & & & & & & 274 & 23 & 19 & 9 & 4 & 0 & 3 & 0 \\
\hline 1995 & 494 & & & & & & & & & & & & 252 & 28 & 56 & 19 & 4 & 1 & 4 \\
\hline 1996 & 288 & & & & & & & & & & & & & 208 & 13 & 4 & 0 & 0 & 0 \\
\hline 1997 & 164 & & & & & & & & & & & & & & 128 & 7 & 1 & 0 & 0 \\
\hline 1998 & 220 & & & & & & & & & & & & & & & 145 & 11 & 7 & 2 \\
\hline 1999 & 145 & & & & & & & & & & & & & & & & 110 & 11 & 3 \\
\hline 2000 & 130 & & & & & & & & & & & & & & & & & 87 & 12 \\
\hline 2001 & 100 & & & & & & & & & & & & & & & & & & 67 \\
\hline
\end{tabular}

Editorial responsibility: Otto Kinne (Editor-in-Chief), Oldendorf/Luhe, Germany
Submitted: December 27, 2004; Accepted: March 22, 2005 Proofs received from author(s): July 22, 2005 